\title{
Effects of Ethanol Extract from Sunkist (Citrus sinensis L. Osbeck) Peels on Rat's Estrus Cycle
}

\author{
Maya Sari Mutia, ${ }^{1}$ Suhartina ${ }^{2}$ \\ ${ }^{1}$ Department of Histology, Faculty of Medicine, Universitas Prima Indonesia, Medan, Indonesia \\ ${ }^{2}$ Department of Public Health, Faculty of Medicine, Universitas Prima Indonesia, Medan, Indonesia
}

\begin{abstract}
Kuhnle et al. has reported that Sunkist peels contain $36 \mu \mathrm{g} / 100 \mathrm{~g}$ wet weight of phytoesterogen. This study was designed to explore Sunkist peels' potential to recover the infertility due to ovulation failure. This study was performed in June 2020 at the Pharmacology Laboratory, Universitas Prima Indonesia, on 25 rats. These rats were divided into five groups: Control, Standard, and Sunkist Peels Extract-I, II, and III that received $1 \mathrm{ml}$ of $0.5 \%$ Sodium Carboxymethyl cellulose suspension, ethinyl estradiol $50 \mathrm{~g} / \mathrm{kgBB}, 300 \mathrm{mg} / \mathrm{kgBW}, 450 \mathrm{mg} / \mathrm{kgBW}$, and 600 $\mathrm{mg} / \mathrm{kg}$ BW of ethanol extract from Sunkist peel, respectively. Every 8-12 hours, the rat's vagina were swabbed and smear into on object glass to be stained by $10 \%$ Giemsa and viewed at 40x and 100x magnifications. The leucocytes, especially neutrophils, epithelial cells, cornified and epithelial cells as well as the density of cells in vaginal swab were evaluated to determine the estrus cycle of the rats. The length of estrus phases was express as median (IQR) and analyzed using the Kruskall-Wallis test. The result of this study showed that the standard and highest dosage extract showed a significant extending of estrus and metestrus phases compared to the control group and significantly shortened diestrus phases. Hence, the highest dosage of Sunkist extract can prevent infertility by increasing the period of estrus cycle (ovulation) at the same level as the standard group.
\end{abstract}

Keywords: Estrus, ethinyl estradiol, Sunkist peels, vaginal swab

\section{Pengaruh Ekstrak Etanol Kulit Sunkist terhadap Siklus Estrus Tikus}

\begin{abstract}
Abstrak
Kuhnle et al. telah melaporkan bahwa kulit Sunkist mengandung fitoesterogen sebesaR $36 \mu \mathrm{g} / 100 \mathrm{~g}$ berat basah. Penelitian ini dirancang untuk mengeksplorasi potensi kulit Sunkist untuk memulihkan infertilitas akibat kegagalan ovulasi. Penelitian ini dilakukan pada Juni 2020 di Laboratorium Farmakologi, Universitas Prima Indonesia dan menggunakan 25 ekor tikus yang dibagi atas lima kelompok, yaitu: kontrol, standar, ekstra kulit sunkist-I, II, dan III yang menerima $1 \mathrm{~mL}$ suspensi 0,5\% Sodium Carboxymethyl cellulose, etinilestradiol $50 \mu \mathrm{g} /$ $\mathrm{kgBB}, 300 \mathrm{mg} / \mathrm{kgBB}, 450 \mathrm{mg} / \mathrm{kgBB}$, dan $600 \mathrm{mg} / \mathrm{kgBB}$ ekstrak etanol kulit sunkist. Setiap 8-12 jam, vagina tikus diusap dan dioleskan ke kaca objek. Kemudian, usapan vagina diwarnai dengan Giemsa 10\% dan dilihat pada pembesaran 40x dan 100x. Leukosit terutama neutrofil, sel epitel, sel epitel terkornifikasi, dan densitas sel pada usap vagina dievaluasi untuk mengetahui siklus estrus tikus. Panjang fase estrus dinyatakan sebagai median (IQR) dan dianalisis dengan kruskall-wallis. Hasil penelitian menunjukkan bahwa ekstrak dosis standar dan dosis tertinggi menunjukkan perpanjangan fase estrus dan metestrus yang signifikan dibanding dengan kelompok kontrol dan memendekkan fase diestrus secara signifikan. Oleh karena itu, ekstrak sunkist dosis tertinggi dapat mencegah kemandulan dengan meningkatkan periode siklus estrus (ovulasi) sebaik kelompok standar.
\end{abstract}

Kata kunci: Etinil estradiol, estrus, kulit sunkist, usapan vagina

Corresponding Author: Maya Sari Mutia, Departemet of Histology, Faculty of Medicine, Universitas Prima Indonesia, Jalan Belanga No.1 Simp. Ayahanda Medan, North Sumatra, Indonesia, Email: mayasarimutia11@gmail.com 


\section{Introduction}

During puberty, primary oocytes in primary follicles in the ovary undergo meiosis to form polar bodies and an ovum that will be released for conception during ovulation. Typically, the ovarium contains 300,000 reserve follicles. However, onlyaround 400 follicles becomemature and can be ovulated, while the remaining $99.7 \%$ will degrade. ${ }^{1}$ Ovulation is affected by various hormones, such as FSH (Follicle-Stimulating Hormone), LH (Luteinizing Hormone), estrogen, and progesterone. Before ovulation, estrogen takes a dominant role, while progesterone is dominant after ovulation. Normally, the estrogen level before menopause or premenopause is 30$400 \mathrm{pg} / \mathrm{mL}$ and is reduced at postmenopausal age to $0-30 \mathrm{pg} / \mathrm{mL}^{1,2}$

Infertility is a typical case found globally. Some reports show that the prevalence of infertility ranged from $9-18 \%$ among the general population. On the other hand, Novakovic et al. reported that more than 7 million individuals have conceived by Assisted Reproductive Technologies (ART) from 1978 until 2019.,3

Around 15\% (48.5 million cases) of couples worldwide have infertility problems, where $17 \%$ of them come from industrial countries. The causes of infertility are, among others, ovulation failure, uterine tube damage, endometriosis, and a lower number in spermatozoa. ${ }^{5,6}$ In Indonesia, the Central Bureau for Statistics, Statistics Indonesia, reported that there are around 39.8 million women in childbearing age with $10-15 \%$ of them are infertile. ${ }^{7}$

Various factors, both from the male and female sides, can cause infertility; however, more than $70 \%$ of problems are seen in females. Infertility in females can be caused by ovarium, uterine tube, uterine, hypothalamic, hypophysis, or systemic diseases. Around $27 \%$ of the cases are due to ovulation failure, both congenital and due to imbalanced hormones. ${ }^{6,8,9}$

Indonesia is rich in various herbs, including some herbs that may contain phytoestrogens. Phytoestrogen is a natural compound with a similar structure to $17-\beta$-Estradiol (E2) and a common sexual hormone in females. The phytoestrogens are commonly found as isoflavone, prenylflavonoid, coumestans, and lignans. ${ }^{9}$ One of the natural products containing these compounds is Sunkist (Citrus sinensis L. Osbeck) peels. The ethanol extract of Sunkist contains various phytochemicals, including a flavonoid which derivatives may act as the phytoestrogen. Due to its similar structure to the 17- $\beta$-Estradiol (E2), phytoestrogen affects the ovulation cycle. Therefore, the high intake of phytoestrogen may make the hypophysis increases the secretion of LH and FSH, which subsequently induces ovulation. Since one of the infertility causes is ovulation failure, phytoestrogens from the Sunkist peel may modify the ovulation cycle and prevent ovulation failure. Thus, this study was designed to explore the potential of Sunkist peels to prevent infertility caused by ovulation failure. ${ }^{10,11}$

\section{Methods}

This was an experimental study performed in June 2020 at the Pharmacology Laboratory of the Faculty of Medicine, Universitas Prima Indonesia. This study was approved by the Health Research Ethics Committee of Universitas Prima Indonesia under the registration no. 012/ KEPK/UNPRI/V/2020.

The materials used in this study were 96\% ethanol, Sunkist peels, sodium carboxymethylcellulose (Na-CMC), Ethinyl Estradiol (Lynoral $®$ ), aqua dest, rat pellets, chloroform, Giemsa staining (Catalogue Number: 109204), and alcohol. Female Wistar aged 3-6 months and weighed 200-220 grams were used as the animal models. The sample size was estimated by the Federer formulation, with a requirement that $\mathrm{n}$ should be higher than 4.75 . Therefore, this study was performed on 25 Wistar rats, which were divided into five groups: control, standard, Sunkist Peels Extract-I, II, and III. All rats were acclimatized for two weeks before receiving the intervention.

The Sunkists used in this study were obtained from one of the traditional markets in Medan City and were identified at the Medanese Herbarium at The Faculty of Math and Science of University of North Sumatra. Five hundred grams of Sunkist peel was dried by aeration for seven days and then pulverized into the simplicia powder form.

The simplicia powder was extracted using the maceration method. Firstly, the powder was macerated by $70 \%$ ethanol as a solvent in a ratio of 1:10 for three days. The mixture was stirred regularly every day. After three days, the mixture was filtered by filter paper and the residue was then re-macerated with $600 \mathrm{~mL}$ of $70 \%$ ethanol for three days. The filtered re-macerated and macerated powder was evaporated by rotary evaporator at a temperature of $70^{\circ} \mathrm{C}$ and then concentrated using an oven at $40^{\circ} \mathrm{C}$ until it became thick extract. ${ }^{12,13}$ 
The ethanol extract of Sunkist peels was then suspended into the sodium carboxymethylcellulose to form an oral suspension. The oral suspension used $0.5 \%$ Sodium Carboxymethyl cellulose as a vehiculum, which was made by mixing 0.5 grams Sodium Carboxymethyl cellulose powder into $30 \mathrm{~mL}$ hot aquadest in a mortar for 15 minutes until it formed a clear phase. It was then grounded to homogeny and dissolved in a volumetric flask by the remaining aqua dest. This suspension was also used by the vehiculum for extract and standard drugs. ${ }^{12}$

The ethinyl estradiol and Sunkist peels extract were suspended into the vehiculum in the next step, with $50 \mu \mathrm{g}$ of ethinyl estradiol was suspended into the $5 \mathrm{~mL}$ vehiculum to form the ethinyl estradiol suspension. Meanwhile, the $300 \mathrm{mg}, 450 \mathrm{mg}$, and $600 \mathrm{mg}$ of Sunkist peels extract were suspended into $5 \mathrm{~mL}$ of vehiculum to form an oral suspension of Sunkist orange peel extract at a dose of $300 \mathrm{mg} / \mathrm{kgBW}, 450 \mathrm{mg} /$ kgBW, and $600 \mathrm{mg} / \mathrm{kgBW}$, respectively. ${ }^{14}$ These oral suspensions were given to each rat group.

Every 8-12 hours, the rats' vaginals were swabbed by rotating a cotton swab that had been soaked into normal saline to the vaginal wall $360^{\circ}$. These vaginal swabs were smeared on a glass slide, and the slide was dried and fixed with methanol for 5 minutes, and stained with 10\% Giemsa for 30 minutes. The preparations were washed carefully with running water and then dried. The slides were viewed by a microscope at $100 \mathrm{x}$ and $400 \mathrm{x}$ magnification. ${ }^{15,16}$

The vaginal swabs were evaluated based on the presence of leucocytes, especially neutrophils, epithelial cells, cornified epithelial cells, and the density of cells. The estrus phase was classified as proestrus, estrus, metestrus, and diestrus, based on the components. ${ }^{15,16}$

The length of each phase of the estrus cycle was shown as median (range) and analyzed by Kruskal-Wallis and Mann-Whitney. On the other hand, the total length of estrus cycles was shown as mean \pm SD and analyzed by one-way ANOVA and Post-Hoc Test Games Howell.

\section{Results}

Vaginal swabs were obtained from each rat after 14 days of treatment and the microscopic view of some vaginal swabs were depicted in Figure 1 whereas the length of each phase and the overall cycle were shown in Table 1.

Based on Table 1, the provision of the standard and highest dose of Sunkist extract led to a significant extended estrus and metestrus phases than the control group and significantly shortened diestrus phases. On the contrary, the other two lower dosage groups showed an extended estrus and metestrus phase, but they did not reach the standard group's length of phase. They also showed a shortened diestrus, but they did not attain the standard group's length of the diestrus phase. Furthermore, no significant difference was seen in the estrus cycle's total length of each group when compared to the control group, except for the group that received the lower dose of Sunkist peel extract. As a comparison, the normal length of each estrus cycle was shown in Table 2.

Table 1 Analysis of Length of Estrus Phases and Estrus Cycles in Treatment Group

\begin{tabular}{|c|c|c|c|c|c|}
\hline \multirow{2}{*}{ Groups } & \multicolumn{4}{|c|}{ Cycle (Hours)* } & \multirow{2}{*}{$\begin{array}{l}\text { Total Length } \\
\text { of Cycle** }\end{array}$} \\
\hline & Proestrus & Estrus & Metestrus & Dietrus & \\
\hline Control & $8.00(1.00)$ & $33.50(12.00)$ & $10.00(1.00)$ & $48.00(24.00)$ & $100.30 \pm 9.38$ \\
\hline Standard & $7.00(0.00)^{\mathrm{a}}$ & $56.00(12.00)^{a}$ & $12.00(0.00)^{\mathrm{a}}$ & $16.00(10.00)^{\mathrm{a}}$ & $90.60 \pm 5.23$ \\
\hline $\begin{array}{l}\text { Sunkist Peels Extract-I } \\
(300 \mathrm{mg} / \mathrm{kgBW})\end{array}$ & $8.00(1.00)^{\mathrm{b}}$ & $30.00(12.00)^{\mathrm{b}}$ & $10.00(1.00)^{\mathrm{b}}$ & $24.00(24.00)^{a b}$ & $81.20 \pm 13.66^{a}$ \\
\hline $\begin{array}{l}\text { Sunkist Peels Extract-II } \\
(450 \mathrm{mg} / \mathrm{kgBW})\end{array}$ & $8.00(1.00)^{\mathrm{b}}$ & $36.00(32.00)^{\mathrm{b}}$ & $12.00(2.00)^{\mathrm{a}}$ & $24.00(24.00)^{\mathrm{ab}}$ & $88.90 \pm 18.00$ \\
\hline $\begin{array}{l}\text { Sunkist Peels Extract-III } \\
(600 \mathrm{mg} / \mathrm{kgBW})\end{array}$ & $7.00(0.00)$ & $56.00(12.00)^{\mathrm{a}}$ & $12.00(3.00)^{\mathrm{a}}$ & $16.00(6.00)^{\mathrm{a}}$ & $91.70 \pm 5.33$ \\
\hline p-value & $<0.05$ & $<0.05$ & $<0.05$ & $<0.05$ & 0.001 \\
\hline
\end{tabular}

* p-value was obtained from Kruskall wallis and Mann-Whitney and data was expressed as median (Range); ${ }^{* *}$ p-value

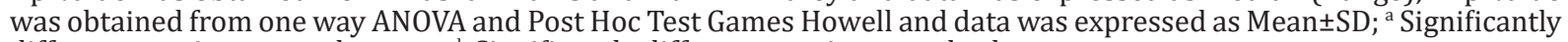
difference against control groups; ${ }^{\mathrm{b}}$ Significantly difference against standard group 
Table 2 Cycle Length of Estrus Phases ${ }^{16}$

\begin{tabular}{lc}
\hline \multicolumn{1}{c}{ Phase } & Cycle Length (Hours) \\
\hline Proestrous & $<14$ \\
Estrus & $24-48$ \\
Metestrus & $6-8$ \\
Diestrus & $48-72$ \\
\hline
\end{tabular}

Based on the values in Table 2, the proestrus length from all groups was shorter than the normal range and this pattern was similar pattern for the diestrus length. The diestrus length was shorter than the normal range, except for the control group. On the contrary, the estrus and metestrus phases were shown to be longer than the normal range. The estrus phase from the rats was determined by evaluation of the microscopic view of the vaginal swab.

Figure 1 presented the serial of the estrus cycle in the animal model. Figure 1A, 1C, 1E, and
$1 \mathrm{G}$ depict the microscopic view of the vaginal swab at $100 \mathrm{x}$ magnification. Meanwhile, the Figure viz. 1B, 1D, 1F, and $1 \mathrm{H}$ demonstrate the microscopic view of the vaginal swab at $400 \mathrm{x}$ magnification. The figure shows the serial estrus cycle that includes estrus, proestrus, metestrus, and diestrus. The determination of the estrus phase was based on the following criteria.

Based on Table 3, it was clear that the estrus phase from the vaginal swab in Figure 1 matched the criteria of each estrus cycle. The cells density was lower in the proestrus (Figure $1 \mathrm{~A}$ and $1 \mathrm{~B}$ ) and diestrus (Figure $1 \mathrm{G}$ and $1 \mathrm{H}$ ) phases. In contrast, the estrus (Figure 1C and 1D) and metestrus (Figure 1E and $1 \mathrm{~F}$ ) phases had a higher density of cells. Other than using the density, the estrus cycle can be determined by leucocyte count of the vaginal swab. The leucocyte count was higher in the metestrus and diestrus cycles, and lower in others. The leucocyte is marked as

Table 3 Determination of Rats Estrus Cycle from Vaginal Swab ${ }^{16}$

\begin{tabular}{|c|c|c|c|c|c|}
\hline Phase & Neutrophil & $\begin{array}{c}\text { Small } \\
\text { Nucleated } \\
\text { Epithelial } \\
\text { Cells }\end{array}$ & $\begin{array}{c}\text { Large } \\
\text { Nucleated } \\
\text { Epithelial } \\
\text { Cells }\end{array}$ & $\begin{array}{c}\text { Anucleated } \\
\text { Keratinized } \\
\text { Epithelial Cell }\end{array}$ & $\begin{array}{c}\text { Relative Cell } \\
\text { Density }\end{array}$ \\
\hline Proestrus & 0 to + & ++ to +++ & 0 to + & 0 to + & Low-Moderate \\
\hline Estrus & 0 to + & 0 to ++ & 0 to ++ & ++ to +++ & Moderate-High \\
\hline Metestrus & + to +++ & + to ++ & + to ++ & + to +++ & Moderate-High \\
\hline Diestrus & ++ to +++ & + to ++ & + to ++ & 0 to + & Low-Moderate \\
\hline
\end{tabular}
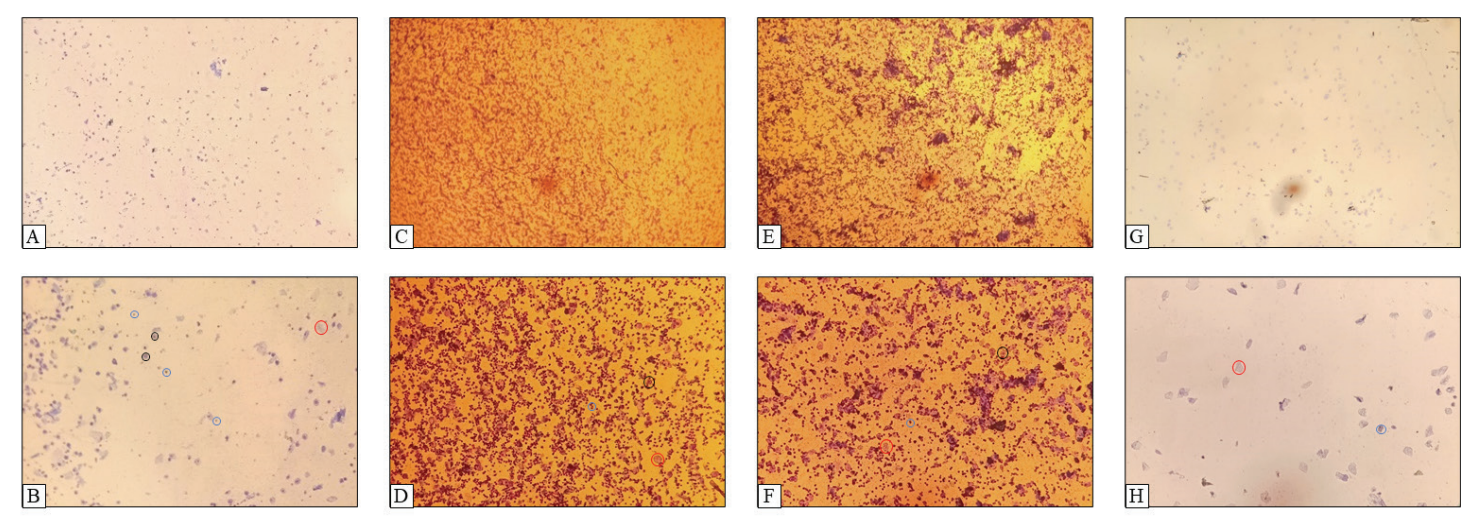

Figure Vaginal Swab along the Estrus Cycle

(A) and (B) were proestrus as determined by the low density of cells, a low number of neutrophils, and many epithelial cells. (C) and (D) were estrus as determined by the higher density of cells, a low number of neutrophils, and many epithelial cells. (E) and (F) were metestrus as determined by the higher density of cells and abundant neutrophil and epithelial cells. $(\mathrm{G})$ and $(\mathrm{H})$ were diestrus as determined by the low density of cells, a high number of neutrophils, and a a low number of epithelial cells. Blue, red, and black circles on the figure were neutrophil, anucleated, and nucleated epithelial cells, respectively 
the rounded cell with a size that is smaller than the epithelial cells.

\section{Discussion}

This study proved the potentials of the Sunkist peels to improve infertility by demonstrating not only a longer estrus phase but also by a shorter total length of the estrus cycle. The estrus cycle of the rats is considered as an analogy to the human menstrual cycle.

The rat group that received the highest dosage of Sunkist peels extract had a prolonged estrus phase compared to the standard group. The prolonged phase will increase the opportunity for conception for the rats. Moreover, the rats that received the highest dose of the extract also showed a shorter total length of the cycle, preventing the delay of the next ovulation process.

Rat as rodent animal has an estrous cycle similar to the human menstrual cycle (ovarian and uterine cycles). The estrus phases include proestrus, estrus, metestrus, and diestrus that occur around 4 to 5 days. The rats' first estrous cycle begins after the pulsatile release of Luteinizing hormone (LH) after the fourth postnatal week (about 30 days). Afterwards, the rats are in puberty and, after hitting the first puberty, the rats are within anestrus phases for 8 to 9 days before entering their first proestrus, estrus, metestrus, and diestrus. ${ }^{17}$

The rat estrous cycle resembles the human menstrual cycle. The proestrus phase of the rat corresponds to the human follicular stage. This phase is affected by the increasing estradiol and a little surge of prolactin that leads to the increase of LH and Follicle Stimulating Hormone (FSH). When the FSH reaches the peak concentration, it will cause a rapid decline of the estradiol level. Subsequently, the ovulation occurs based on the rat's estrus phase. Consequently, the progesterone hormone becomes dominant, leading to the metestrus and diestrus phase. These cycles are reassembled in early and late human secretory stages, respectively. ${ }^{16}$

This study show that the estrus phase in the estrous cycle of the group receiving the highest dose of Sunkist extract is longer. The lengthening of the estrus cycle in the highest extract dose group is due to the presence of phytoestrogen in the Sunkist peel extract. Phytoestrogen has a similar structure to endogen estradiol and binds with the alpha and beta receptors of estrogen. This complex will influence the gene expression of the cells. Kuhnle et al. reported that orange peels contain $36 \mu \mathrm{g} / 100 \mathrm{~g}$ wet weight of phytoestrogen based on the LC-MS and ${ }^{13} \mathrm{C}$-Labelled standard. ${ }^{18}$

Also, Shalaby et al. reported that the presence of flavanones, flavones, and flavonols in Citrus sinensis and Citrus aurantifolia leaf or peel leads to a powerful estrogen-like activities. When the phytoestrogen affects the ovarium, it will affect the oocyte maturation and interfere with the estrous cycle. The extension becomes important because it can reduce the cumulative number of cycles and become very important in the fertility cycle. ${ }^{14,19,20}$

Overall, it can be concluded that the highest dose of Sunkist extract of $600 \mathrm{mg} / \mathrm{kgBW}$ could prevent infertility by increasing the period of the estrus cycle (ovulation).

\section{Acknowledgment}

This study was fully funded by the Ministry of Research, Technology, and Higher Education by Funding Contact No. 282/LLI/PG/2020.

\section{References}

1. Sherwood L. Fisiologi manusia dari sel ke sistem. Fisiologi manusia dari sel ke sistem. Jakarta: EGC; 2013.

2. Simon A, Chang WY, Cherney AH De. Amenorrhea. In: DeCherney AH, Nathan L, Lauger N, Roman AS, editors. Current diagnosis \& treatment obstetrics \& gynecology. $11^{\text {th }}$ ed. New York: Mc Graw Hill Medical; 2013. p. 1514-35.

3. Novakovic B, Lewis S, Halliday J, Kennedy J, Burgner DP, Czajko A, et al. Assisted reproductive technologies are associated with limited epigenetic variation at birth that largely resolves by adulthood. Nat Commun. 2019;10(1):3922.

4. Hanson B, Johnstone E, Dorais J, Silver B, Peterson CM, Hotaling J. Female infertility, infertility-associated diagnoses, and comorbidities: a review. J Assist Reprod Genet. 2017;34:167-77.

5. Bhattacharya S, Johnson N, Tijani HA, Hart RJ, Pandey S, Gibreel AF. Female Infertility. BMJ Publ Gr Ltd. 2010;11(819):1-47.

6. Agarwal A, Mulgund A, Hamada A, Chyatte MR. A unique view on male infertility around the globe. Reprod Biol Endocrinol. 2015;13(37):1-9.

7. Sharma S, Khinchi MP, Agrawal NSD, Gupta 
MK. Female Infertility: an overview. IJPSR. 2011;2(1):1-12.

8. Hoffman, Corton S, Bradshaw, Halvorson, Schaffer. Williams Gynecology Third Edition. New York: Mc Graw Hill; 2016.

9. Oikeh, Oriakhi EI, Omoregie K. Proximate analysis and phytochemical screening of citrus sinensis fruit wastes. Biosci. 2013;1(2):164-70.

10. Rietjens IMCM, Louisse J, Beekmann K. The potential health effects of dietary phytoestrogens. Br J Pharmacol. 2017; 174(11):1263-80.

11. Sa'adah N, Purnomo W. Karakteristik dan perilaku berisiko pasangan infertil di klinik fertilitas dan bayi tabung tiara cita Rumah Sakit Putri Surabaya. J Biometrika Kependud. 2017;5(1):61-9.

12. Mutia MS, Chiuman L. Hepatoprotective Effect of citrus sinensis (L.) osbeck ethanol extract in paracetamol-induced rats efek hepatoprotektif ekstrak etanol citrus sinensis L. osbeck pada tikus yang diinduksi parasetamol. MKB. 2019;51(4):189-93.

13. Kosasih E, Chiuman L, Lister INE, Fachrial E. Hepatoprotective effect of citrus sinensis peel extract against isoniazid and rifampicininduced liver injury in wistar rats. Maj Obat Tradis. 2019;24(3):197-203.

14. Maheshwari H, Satyaningtijas AS, Harlina E,
Ningsih UC, Effendi M, Mustofa MA, et al. The role of fennel infusion on estrous cycle and follicles development of white rats. J Ilmu Kefarmasian Indones. 2016;14(1):19-25.

15. Byers SL, Wiles M V., Dunn SL, Taft RA. Mouse estrous cycle identification tool and images. PLoS One. 2012;7(4):e35538.

16. Cora MC, Kooistra L, Travlos G. Vaginal cytology of the laboratory rat and mouse:review and criteria for the staging of the estrous cycle using stained vaginal smears. Toxicol Pathol. 2015;43(6):776-93.

17. Ngadjui E, Watcho P, Nguelefack TB, Kamanyi A. Effects of Ficus asperifolia on normal rat estrus cyclicity. Asian Pac J Trop Biomed. 2013;3(1):53-7.

18. Kuhnle GGC, Dell'Aquila C, Aspinall SM, Runswick SA, Joosen AMCP, Mulligan AA, et al. Phytoestrogen content of fruits and vegetables commonly consumed in the UK based on LC-MS and 13C-labelled standards. Food Chem. 2009;116(2):542-54.

19. Desmawati D, Sulastri D. Phytoestrogens and their health effect. Open Access Maced J Med Sci. 2019;7(3):495-9.

20. Shalaby E a, Shanab SMM. Antioxidant compounds, assays of determination and mode of action. African J Pharm Phamacology. 2013;7(10):528-39. 